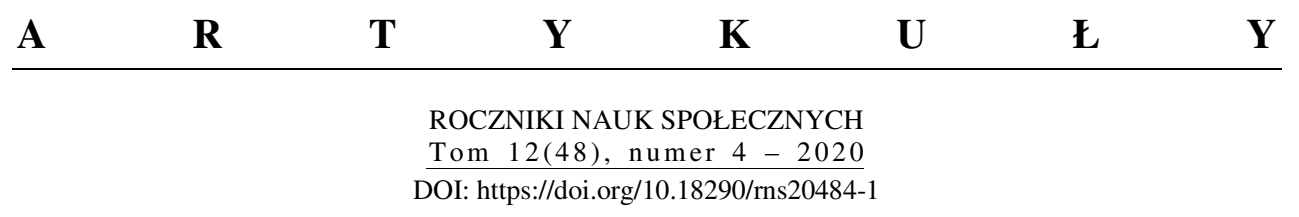

ROBERT SZWED

\title{
FUNKCJE MEDIÓW W DEMOKRACJACH
}

U podstaw demokracji leżą trzy normatywne założenia: (1) musi istnieć sfera, w której toczy się swobodna rywalizacja między podmiotami rynku politycznego, (2) obywatele jako suweren władzy muszą mieć zagwarantowane prawo uczestnictwa w wolnych i uczciwych wyborach, (3) zagwarantowane i przestrzegane są prawa i swobody obywatelskie, a wśród nich: prawo do swobodnej wypowiedzi, publikacji i zgromadzeń, które umożliwiają realizację zasad konkurencji i uczestnictwa w sferze publicznej ${ }^{1}$.

W ten sposób rywalizacja, uczestnictwo i dyskusja stanowią fundament demokracji, a media stanowią idealną przestrzeń, w której mogą się one w praktyce realizować. „Sposób, w jaki rozumiemy demokrację, zależy od form komunikacji, przy użyciu których prowadzimy politykę. Sposób rozumienia komunikacji jest funkcją zasadniczych impulsów i aspiracji polityki demokratycznej. To, czym jest opinia publiczna, zależy od obu tych elementów"2. W artykule przedstawione zostaną wymiary, w jakich demokracja i media wzajemnie się przenikają, oraz funkcje, jakie względem siebie spełniają.

Dr hab. ROBERT SzweD - Instytut Dziennikarstwa i Zarządzania, Katolicki Uniwersytet Lubelski Jana Pawła II, adres do korespondencji: Al. Racławickie 14, 20-950 Lublin; e-mail: szwed@kul.pl; ORCID: https://orcid.org/0000-0002-2700-0292 .

${ }^{1}$ Zob. m.in.: G. O’Donnell, Illusions about Consolidation, „Journal for Democracy” 1996, nr 7 (2), s. 34-51; L. DiAmond, Is the Third Wave Over?, ,Journal of Democracy” 1996, nr 7 (3), s. 20-37, czy A. ANTOSZEWSKI, Perspektywy demokracji w Europie Środkowo-Wschodniej, w: Demokracje Europy Środkowo-Wschodniej w perspektywie porównawczej, red. A. Antoszewski, R. Herbut, Wrocław: Wydawnictwo Uniwersytetu Wrocławskiego 1998, s. 223-249; A. ANTOSZEwSKI, Modele demokracji przedstawicielskiej, w: Demokracje zachodnioeuropejskie. Analiza porównawcza, red. A. Antoszewski, R. Herbut, Wrocław: Wydawnictwo Uniwersytetu Wrocławskiego 1997, s. 15-38.

${ }^{2}$ J.W. CARey, The Press, Public Opinion, and Public Discourse, w: Public Opinion and the Communication of Consent, red. T.L. Glaser, C.T. Salmon, New York: The Guilford Press 1995, s. 378-379. 


\section{WSPÓŁZALEŻNOŚĆ MEDIÓW I DEMOKRACJI}

Siła mediów jest rezultatem natychmiastowości przekazu, zasięgiem oddziaływania, zależy od formy komunikatów i zwiększa się wraz ze zwielokrotnieniem treści w powszechnym systemie komunikacji. Spektakularne przykłady skuteczności perswazyjnej „środków urabiania publiczności” ${ }^{3}$ wzmacniają przekonanie o ich wszechmocy. W latach dwudziestych ubiegłego wieku - jak pisał C. Wright Mills - wierzono, że „przy pomocy słów [...] wygrywa się wojnę lub sprzedaje mydło, skłania się ludzi do czynu albo powstrzymuje ich od działania"4. W podobnym tonie Paul F. Lazarsfeld i Robert K. Merton stwierdzali, że siła mediów „może być porównana jedynie z siłą bomby atomowej”.

Skuteczność i siłę oddziaływania mediów politycy, specjaliści od komunikacji medialnej i teoretycy demokracji szybko zdecydowali się wykorzystać. W każdym wypadku zwracano się do opinii publicznej, która pozostawała głównym przedmiotem odniesienia. Jedni zdecydowali się wykorzystać środki komunikacji do działań promocyjnych, służących do kształtowania i przekonywania opinii publicznej. Inni, nakreślając normatywne teorie mediów w demokracji, dążyli do jej udoskonalenia poprzez edukację i upodmiotowienie.

Choć media spełniają w sferze publicznej różne funkcje, wielu analityków zdaje się o tym zapominać. „Teoretycy” w swoich koncepcjach i postulowanych zadaniach mediów często abstrahują od tego, że ich celem nie jest wyłącznie edukacja obywateli, wypełnianie funkcji „,czwartej władzy”, lecz również - jak przypominał Walter Lippmann, a obecnie np. Michael Schudson - „zarabianie pieniędzy dla właścicieli, generowanie miejsc pracy, budowanie prestiżu zawodowego, dostarczanie rozrywki konsumentom”. „Wszystkie te cele - pisze Schudson - mają rację bytu" ". Z kolei ,praktycy mediów” zapominają, że media mogą rzeczywiście przyczynić się do „osłabienia demokracji”, a ich rola wykracza znacząco poza zarabianie pieniędzy i budowanie wrażenia.

\footnotetext{
${ }^{3}$ Dowodząc wpływu mediów na społeczeństwa, zwykle wskazuje się na efektywność propagandową Stanów Zjednoczonych w okresie I wojny światowej, Rzeszy Niemieckiej w okresie przejmowania władzy przez nazistów i sowieckiej Rosji w okresie powojennym. Warto pamiętać o bardziej współczesnych i bliskich przykładach, jak panika w Gruzji, wywołana materiałem o domniemanej inwazji na ten kraj Rosji, czy reklama przynosząca zyski komunikującym się w ten sposób usługodawcom, producentom lub... partiom politycznym.

${ }^{4}$ C.W. Mills, Elita władzy, Warszawa: Książka i Wiedza 1961, s. 414.

${ }^{5}$ P.F. LaZARSFeld, R.K. Merton, Mass Communication, Popular Taste and Organized Social Action, w: Mass Communications, red. W. Schramm, Urbana: University of Illinois Press 1960, s. 487-526.

${ }^{6}$ M. Schudson, The Power of News, Cambridge: Harvard University Press 1996, s. 204-205.
} 
Media znacznie częściej są obiektem krytyki niż pochwał, szczególnie jeśli chodzi o ich rolę $\mathrm{w}$ demokracji ${ }^{7}$. Zdaniem wielu badaczy zamiast być „,czwartą władzą”, są dyspozycyjne wobec trzech pozostałych ${ }^{8}-$ zamiast reprezentować pluralizm na rynku opinii, poprzez koncentrację własności, stanowią raczej rywalizujące ze sobą konglomeraty medialne, w których interesie leży utrzymanie status quo ${ }^{9}$. Przyczyniają się do politycznego cynizmu, irytacji, braku wiedzy i zniechęcają obywateli do zaangażowania w życie publiczne ${ }^{10}$. Ukazują politykę jako grę, a obywateli jako przedmiot rozgrywki $^{11}$, trywializują ją, skupiając się na wątkach sensacyjnych, plotkach ${ }^{12}$ i zmuszają polityków do podporządkowania się logice medialnej w działalności publicznej ${ }^{13}$. W ten sposób zamiast przyczyniać się do rozwoju, media obniżają standardy demokratyczne. Nie są zainteresowane przedstawianiem

${ }^{7} \mathrm{O}$ ich pozytywnej roli, jaka wyłania się z badań, rzecz jasna nie można zapominać. W badaniach wskazuje się m.in. na to, że media zwiększają wiedzę i świadomość obywatelską (np. D.A. SCHEUFELE, Examining differential gains from mass media and their implication for participatory behavior, „Communication Research” 2002, nr 29, s. 46-65), zwiększają obywatelskie zaangażowanie (np. K. StAmm, A. EMIG, M. Hesse, The contribution of local media to community involvement, „Journalism \& Mass Communication Quarterly” 1997, nr 74, s. 97-107) czy też są czynnikiem „obywatelskiej socjalizacji” (np. R. MATTES, M. BRATTON, Learning about democracy in Africa: Awareness, performance, and experience, „American Journal of Political Science” 2007, nr 51, s. 192-217).

${ }^{8}$ Mówi się tutaj o roli mediów jako „pieska salonowego” (lapdog), strażnika „interesu elit” ( guarddog), co ma stanowić przeciwieństwo ich postulowanej funkcji strażnika wartości demokratycznych (watchdog).

${ }^{9}$ D. Kellner, The Media and Social Problems, w: Handbook of Social Problems: A Comparative International Perspective, red. G. Ritzer, Thousand Oaks: Sage 2004; E.S. HeRMAN, N. CHOMSKY, Manufacturing Consent: The Political Economy of the Mass Media, New York: Pantheon 1988; R.W. McChesney, Rich Media, Poor Democracy: Communication Politics in Dubious Times, Urbana: University of Illinois Press 1999.

${ }^{10}$ M. Schudson, The Concept of Politics in Contemporary U.S. Journalism, ,Political Communication” 2007, nr 24 (2), s. 131-142; T.E. PATTERSON, Doing well and doing good: How soft news and critical journalism are shrinking the news audience and weakening democracy - And what news outlets can do about it, Cambridge: Joan Shorenstein Center on Press, Politics, and Public Policy, Kennedy School of Government, Harvard University 2002; J.N. CAPPELLA, K.H. JAMIESON, Spiral of Cynicism. The press and the public good, New York: Oxford University Press 1997.

${ }^{11} \mathrm{~W}$ tym kierunku idzie np. krytyka T.E. Pattersona (Out of Order. New York: Vintage Books 1993) i wielu innych autorów.

${ }^{12}$ B. FrankLin, Packaging Politics: Political Communications in Britain's Media Democracy, London: Arnold 2002; B. MCNAIR, News and Journalism in the UK, London: Routledge 2003; S. BARnetT, Will a Crisis in Journalism Provoke a Crisis in Democracy?, „The Political Quarterly” 2002, nr 73, s. 400-408.

${ }^{13}$ T. MeYer, Media Democracy. How the media colonize politics, Cambridge: Polity Press 2002; D.L. Altheide, R.P. Snow, Media Worlds in the Postjournalism Era, New York: Aldine de Gruyter 1991. 
rzeczywistości politycznej jako sfery godnej troskliwego zainteresowania aktywnych obywateli i nie dostarczają opinii publicznej informacji niezbędnych do podjęcia kluczowych decyzji związanych ze sprawowaniem kontroli sfery publicznej i podejmowania decyzji wyborczych.

\section{KLASYFIKACJE FUNKCJI MEDIÓW}

Przyjmując krytykę mediów jako punkt wyjścia, zakłada się, że „służba demokracji” jest podstawowym celem mediów informacyjnych. Szczególne zobowiązania mediów wobec demokracji i opinii publicznej postuluje tzw. nurt „,społecznej odpowiedzialności”, którego koncepcyjne korzenie tkwią w raporcie tzw. Komisji Hutchinsa - „A Free and Responsible Press” z 1947 roku oraz książce Freda S. Sieberta, Theodore'a Petersona i Wilbura Schramma Four Theories of the Press ${ }^{14}$.

Autorzy raportu, uzasadniając znaczenie wolności wypowiedzi, w tym wolności prasy w społeczeństwie demokratycznym, odwoływali się do listu Jeffersona, w którym 16 stycznia 1787 roku pisał on do pułkownika Edwarda Carringtona: „Podstawą naszego rządu jest opinia ludu i to prawo należy utrzymać; i gdyby to ode mnie zależało, czy winien istnieć rząd bez prasy czy prasa bez rządu, nie wahałbym się ani chwili, wybierając tę drugą opcję". Rzecz bowiem leży w tym, czego potrzebują obywatele i aby zasada samorządności - podstawowa zasada w demokracji - została wprowadzona w życie. A opinia publiczna potrzebuje przede wszystkim odpowiedzialnych mediów zapewniających obywatelom dostępną, rzetelną informację. Jakimi cechami, wobec tego, powinny się takie media charakteryzować? Winny być one, po pierwsze, ,prawdziwym, wyczerpującym i inteligentnym sprawozdaniem z tego, co się wydarzyło w ciągu dnia w kontekście, który nada sens wydarzeniom”; po drugie - winny stanowić „forum wymiany myśli i krytyki”; po trzecie, być „reprezentatywnym obrazem odwzorowującym wzajemne opinie i postawy grup w społeczeństwie”; po czwarte - „prezentować i wyjaśniać cele i wartości społeczne"; wreszcie po piąte, winny być tak

\footnotetext{
${ }^{14}$ A Free and Responsible Press. A General Report on Mass Communication: Newspapers, Radio, Motion Pictures, Magazines, and Books, Commission on Freedom of the Press, red. R.D. Leigh, Chicago: Chicago University Press 1947; F.S. Siebert, T. Peterson, W. Schramm, Four Theories of the Press. The Authoritarian, Libertarian, Social Responsibility and Soviet Communist Concepts of What the Press Should Be and Do, Chicago: Chicago University Press 1956.
} 
powszechne i dostępne, aby objąć swym zasięgiem „wszystkich członków społeczeństwa"15.

Wielu teoretyków i badaczy, odwołując się wprost lub pośrednio do dokumentu opracowanego przez Komisję Hutchinsa, zaproponowało własne klasyfikacje. Jeden z pionierów badań nad komunikacją masową Harold Lasswell wskazał na trzy podstawowe funkcje mediów w społeczeństwach ${ }^{16}$ : funkcję nadzorowania (surveillance, czyli dostarczania informacji o tematach ważnych, np. ekonomicznych lub militarnych, które mogłyby stanowić zagrożenie dla publicznego dobrostanu), funkcję śledzenia tego, co się dzieje w środowisku społeczno-politycznym (correlation - czyli wybierania i interpretowania informacji, monitorowania głosów opinii publicznej, nadawania sensu wydarzeniom i działaniom, tworząc podstawę do społecznego porozumienia) i funkcję transmisji kultury z jednego pokolenia na kolejne (transmission - czyli zapewnienia kulturowej ciągłości między generacjami, która zwiększa społeczną spójność i redukuje anomię).

Zestawiając ze sobą normatywne oczekiwania, które formułuje się wobec mediów i praktyczną ich realizację, Michael Gurevich i Jay B. Blumler wymieniają osiem, które są ich zdaniem najważniejsze ${ }^{17}:$ (1) nadzorowanie środowiska społeczno-politycznego i relacjonowanie wszelkich wydarzeń, które mogłyby naruszyć dobrostan obywateli; (2) wyznaczanie hierarchii ważności spraw, ustalając przyczynę wydarzeń i ewentualne sposoby rozwiązania problemów; (3) spełnianie funkcji „zrozumiałej i pouczającej” platformy dyskusji liderów środowisk politycznych i grup nacisku; (4) stanowienie płaszczyzny dialogu między siłami reprezentującymi różnorodne środowiska i „masową publiczność”; (5) spełnianie roli instrumentu rozliczającego rządzących z realizowanej przez nich władzy; (6) zachęcanie obywateli do zaangażowania się w sferę publiczną; (7) „pryncypialna obrona” niezależności, uczciwości i bezstronności mediów przed zakusami różnorodnych instytucji i grup, które uniemożliwiają im służbę społeczeństwu; (8) zachowanie szacunku wobec odbiorców przekazów jako podmiotów nadających dzięki mediom sens rzeczywistości politycznej.

\footnotetext{
${ }^{15}$ A Free and Responsible Press, red. R.D. Leigh, s. 20-29.

${ }^{16}$ H. Lasswell, The Structure and Function of Communication in Society, w: The Communication of Ideas, red. L. Bryson, New York: Harper 1948, s. 32-51. Lasswell wymienił również czwartą funkcję mediów, która służyć miała redukcji stresu, zmęczenia i przyczyniać się do odpoczynku i relaksu opinii publicznej - funkcję rozrywkową, której „służba demokracji” jest jednak wątpliwa.

${ }^{17}$ M. Gurevitch, J.G. Blumler, Political communication systems and democratic values, w: Democracy and the mass media, red. J. Lichtenberg, Cambridge University Press 1990, s. 269-287.
} 
Pippa Norris, nawiązując do schumpeterowskiej wizji demokracji wyróżniła z kolei trzy podstawowe funkcje, które media winny pełnić w czasie kampanii wyborczych: funkcję obywatelskiego forum pluralistycznej debaty (civic forum), funkcję strażnika obywatelskich i politycznych wolności (watchdog) oraz funkcję instytucji mobilizującej obywateli (mobilizing agent) do zaangażowania w proces demokratyczny ${ }^{18}$. W książce $A$ Virtuous Circle Norris wymienia również funkcję strażnika interesu publicznego (news media as watch-dogs - media przybliżają nadużycia władzy, sprzeniewierzenia, korupcji, złego zarządzania mieniem publicznym), funkcję „edukacyjną" - podmiotu odpowiedzialnego za zwiększanie świadomości społecznej i politycznej obywateli i polityków w zakresie najważniejszych problemów, przed którymi stoją społeczeństwa i państwa (news media as agenda-setters) oraz funkcję „strażnika dialogu”, zabezpieczającego pluralizm opinii i wielość argumentów w sferze publicznej (news media as gate-keepers) ${ }^{19}$. Choć Norris sądzi, że „efektywna sfera publiczna zależy od możliwości partycypacji i interakcji w ramach społeczeństwa obywatelskiego"20, to przesuwa ową sferę „partycypacji i interakcji” w obszar pozamedialny lub paramedialny, który stanowi o zaangażowaniu obywatelskim.

Doris Graber, odwołując się do listy zadań mediów przedstawionej przez Gurevitcha i Blumlera oraz Jamesa Currana ${ }^{21}$, przywołuje „bardziej uczestniczącą" koncepcję ich roli w sferze publicznej. Zgodnie z nią media winny spełniać cztery podstawowe funkcje: „(a) stanowić forum dyskusji między różnymi, często przeciwstawnymi punktami widzenia; (b) stanowić tubę dla opinii publicznej; (c) spełniać funkcję „oczu i uszu” obywateli, sondując scenę polityczną i działalność polityków; (d) działać jako „pies łańcuchowy", który głośno ujada, gdy dostrzeże niewłaściwe zachowanie, korupcję, nadużycia władzy na korytarzach rządowych"22. Okazuje się jednak, że owe funkcje - zdaniem Graber - należy umieścić w kategorii mitów nawiązujących do ateńskiej wizji demokracji. „Brak siły, środków, struktury i chęci” powodują, że zadania, które stawia się przed mediami, są niemożliwe do realizacji.

\footnotetext{
${ }^{18}$ P. NorRIS, A Virtuous Circle. Political Communication in Postindustrial Societies, Cambridge: Cambridge University Press 2000, s. 22-35.

${ }^{19}$ P. Norris, S. Odugbemi, Evaluating Media Performance, w: Public Sentinel. News Media and Governance Reform, red. P. Norris, Washington: The World Bank 2010, s. 3-30.

${ }^{20}$ Tamże, s. 10.

${ }^{21}$ J. CuRran, Mass media and democracy revisited, w: Mass Media and Society, red. tegoż London: Arnold 1996, s. 81-119.

${ }^{22}$ D. Graber, The Media and Democracy: Beyond Myths and Stereotypes, „Annual Review of Political Science" 2003, nr 6, s. 139-160.
} 
Podobnie Thomas Patterson, odwołując się do licznych badań nad profilem programów informacyjnych, stwierdza, że „miękkie wiadomości”, które czynią ze sfery polityki jeden z obszarów show-biznesu, nadkrytyczna postawa wobec rzeczywistości politycznej dziennikarzy przyczyniają się do „osłabienia fundamentów demokracji, zmniejszając wiedzę obywateli na temat spraw publicznie dyskutowanych i ich zainteresowanie polityką"23.

Niedoskonałość mediów w zakresie realizacji normatywnych oczekiwań skłoniła Johna Zallera do postawienia raz jeszcze pytania o ich rolę w demo$\mathrm{kracji}^{24}$. Sugeruje on, że zamiast nierealistycznych oczekiwań, które stawiamy mediom i opinii publicznej, powinniśmy zredefiniować ich rolę w sferze publicznej. Zamiast modelu - nazwał go "standardem pełnej informacji” (Full News Standard), w którym media winny zaopatrzyć racjonalnych i krytycznych obywateli „,w podstawową informację niezbędną do zbudowania i zaktualizowania wszystkich najważniejszych wydarzeń, włączając w to działalność najważniejszych decydentów w państwie", należy raczej wprowadzić mniej rygorystyczny „standard łamania zasad” (Burglar Alarm News Standard). Zgodnie z nim obywatele nie są zobowiązani do nieustannego śledzenia tego, co dzieje się w sferze publicznej, a media mają reagować na sytuacje zagrożenia porządku, najbardziej drażliwe, istotne z punktu widzenia społeczności problemy. Przywodząc analogię policyjną, zamiast roli, jaką pełnią patrole krążące w okolicy, media miałyby reagować jedynie na sytuacje alarmowe wywołane włamaniem, przekroczeniem obowiązujących zasad.

Kluczowa w tym kontekście jest odpowiedź na pytanie o sytuacje, w których media mają „wszczynać alarm”, o problemy, które są najistotniejsze z punktu widzenia funkcjonowania państwa. Okazuje się, że są one pojmowane w różny sposób, w zależności od sposobu pojmowania demokracji, postrzegania polityki i roli, jaką w systemie ma odgrywać opinia publiczna. Z tego powodu dla odpowiedzi na pytanie: ,jak ustawić alarm?”, warto wyróżnić trzy podstawowe modele demokracji wraz z ich normatywnymi implikacjami, dotyczącymi sfery publicznej i mediów.

\footnotetext{
${ }^{23}$ T.E. PATTERSON, Doing well and doing good, s. 2.

${ }^{24}$ J. ZALler, A New Standard of News Quality: burglar alarms for the monitorial citizen, „Political Communication” 2003, nr 20 (2), s. 109-31.
} 


\section{MEDIA W DEMOKRACJI LIBERALNEJ, ELITYSTYCZNEJ I UCZESTNICZĄCEJ}

„Teoria demokratyczna nieustannie się zmienia"25 - pisze David Held, nakreślając w swojej książce nie tylko różnice między różnymi odmianami demokracji, ale również znaczące zróżnicowania w ich ramach. Implikują one inne wizje obywatelskości i mediów: od indywidualistycznie pojmowanego społeczeństwa i opinii publicznej w modelu liberalnym do komunitarystycznej wizji współdziałających wspólnot i zorientowanych na współpracę jednostek w modelu uczestniczącym i demokracji deliberatywnej. Każdy z modeli nakłada na polityków, media i dziennikarzy różne obowiązki oraz wyposaża je w inne uprawnienia. Poniżej nakreślone zostaną relacje między mediami a trzema podstawowymi modelami demokracji: modelem liberalnym, elitystycznym i uczestniczącym, deliberatywnym.

W modelu liberalnym podstawowym zadaniem państwa wobec obywateli jest zabezpieczenie ich podstawowych praw i wolności oraz przestrzeganie przez instytucje funkcjonujące $\mathrm{w}$ sferze publicznej demokratycznych procedur. Kluczową koncepcją, która tłumaczy wyłanianie się wspólnego dobra i woli powszechnej jest „wolny rynek idei”, w którym nieskrępowane, ścierające się ze sobą opinie i argumenty prowadzą do wyłonienia się oświeconej i racjonalnej opinii publicznej. Obywatele w tym modelu są postrzegani jako krytyczni aktorzy sfery publicznej, którzy są w stanie odróżnić prawdę od kłamstwa, a w sytuacji konfliktu potrafią wybrać właściwą alternatywę. Podstawową rolę, którą w tym modelu mają wypełnić media, jest „partnerstwo w poszukiwaniu prawdy". W praktyce owa prawda ujawnia się szczególnie w czasie wyborów, gdy racjonalni obywatele mają dokonać decyzji na podstawie uzyskanych dzięki mediom informacji.

Dla mediów i dziennikarstwa kluczowym zadaniem pozostaje ustanowienie obszaru dyskursu niezależnego od władz publicznych i grup interesu, w którym wolność i respektowanie reguł demokratycznych pozostaje najwyższą zasadą. Poruszający się w niej obywatele mogą ocenić funkcjonowanie władzy i działalność jej urzędników i na tej podstawie zweryfikować swoje późniejsze dla nich poparcie. „Wolność mediów” - zgodnie z doktryną liberalną - będzie zabezpieczona, jeśli władza i instytucje publiczne określą i będą przestrzegać reguł nieskrępowanej konkurencji na rynku medialnym. Ta prowadzi do pozytywnych następstw: „Utrzymuje ona niskie ceny i wysoką jakość, zmusza dostawców do podejmowania ryzyka i stałego wprowadzania innowacji po

\footnotetext{
${ }^{25}$ D. Held, Models of democracy, Stanford: Stanford University Press 1996, s. 231.
} 
to, aby nie wypaść z interesu na rzecz rywali oferujących lepsze, udoskonalone produkty. Prywatna prasa i wielokanałowe systemy radia i telewizji, znajdujące się w rękach różnych właścicieli, to bastion wolności”"26.

Jakie funkcje w doktrynie liberalnej mają wypełniać media? Najpełniejszą ich listę przedstawili Gurevitch i Blumler. Z pewnością mają kontrolować władzę, stać na straży obywatelskich wolności, informować o tym, co ważnego dzieje się w sferze publicznej i umożliwiać pluralistyczną dyskusję, w której reprezentowane będą na równych zasadach wszystkie strony sporu. Nie oznacza to wszakże, że media mają wyłącznie edukować co do ważności spraw i organizować dyskurs publiczny. Działają na wolnym rynku, dlatego mają również dostarczyć publiczności produktu, którego ona oczekuje, co oznacza: informować, zabawiać, wzruszać i oferować materiał do refleksji. Należy przy tym zachować równowagę między „,nieprzerwanym dyskursem politycznym” i ,zatraceniem się" w zabawie.

W tym miejscu raz jeszcze warto przywołać koncepcję „standardu łamania zasad" Johna Zallera. Jest ona rozwinięciem refleksji Michaela Schudsona, który opisując rolę mediów i obywateli w sferze publicznej, przywołuje sytuację rodziców pilnujących dzieci na placu zabaw: „Baczą oni na to, co się dzieje wokół. Zdają się być bierni, lecz są gotowi do podjęcia działania, jeśli sytuacja tego będzie wymagać. Monitorujący obywatel nie jest nieobecny, lecz czuwa, nawet wówczas, gdy robi coś zupełnie innego"27. Dlatego właśnie per analogiam nie należy - zdaniem Zallera - zmuszać obywateli i mediów do nieustannego patrolowania sfery publicznej. Przede wszystkim dlatego, że wielu szczerze tego nie pragnie, a inni fakty im przedstawione ocenią jako zbędne. Decyzja o tym, co warto, a czego nie warto prezentować, winna zapadać w konsultacjach między dziennikarzami, przedstawicielami ugrupowań politycznych i społecznych, którzy pomogą podjąć ostateczną decyzję. Same wiadomości nie muszą być przy tym nadzwyczaj poważne, lecz raczej zachęcać odbiorców do zapoznania się z nimi, co czyni zadość niewypowiedzianemu przez teoretyków, lecz nieustannie obecnemu aspektowi działalności dziennikarskiej. Oznacza to, że wiadomość ma zostać obejrzana, a zatem przynieść sukces nadawcy: news musi być komercyjnie optacalny [...], uwzględniajac istniejace uwarunkowania instytucjonalne $i$ kulturowe, nadawcy musza chcieć wyprodukować, a odbiorcy skonsumować wybrany typ newsa ${ }^{28}$.

\footnotetext{
${ }^{26}$ J. KeAne, Media a demokracja, London: Aneks 1992, s. 42.

${ }^{27}$ J. ZALLER, A New Standard of News Quality, s. 118.

${ }^{28}$ Tamże, s. 127.
} 
Oczekiwanie czegoś więcej od mediów i obywateli, jest - zgodnie z zaprezentowaną logiką - zaklinaniem rzeczywistości i prowadzi do wzmacniania fikcji, która nigdy nie istniała i przeto winna być odrzucona, że media mają wyłącznie edukować, a obywatele być edukowani i przedkładać sferę polityki nad inne sfery bytowania człowieka. Należy bowiem pamiętać, że w liberalnej wizji demokracji naczelną wartością jest wolność, w tym wolność czytania i oglądania tego, na co czytelnicy i widzowie mają ochotę. Podobnie jak Zaller, o konieczności przemyślenia funkcji mediów pisał również Clifford G. Christians i in. w Normative Theories of the Media. Jego zdaniem dziennikarze zamiast informować ludzi o sprawach, na które nie mają żadnego wpływu i których nie są w stanie kontrolować, powinni raczej skupić się na sytuacjach kryzysowych, których bohaterami są sprzedajni politycy i niekompetentni liderzy. Szczególną uwagę dziennikarze powinni skupić na kwestiach programowych, obietnicach i ideach głoszonych przez polityków w trakcie kampanii wyborczych ${ }^{29}$.

Inne oczekiwania wobec mediów i obywateli mają zwolennicy koncepcji elitystycznych. W tej wersji demokracji funkcją władzy jest zabezpieczenie praw i wolności obywatelskich, natomiast obywateli, dokonanie wyboru między alternatywami, które rozstrzygną, kto będzie lepiej realizował ich potrzeby. Lud nie rządzi ani bezpośrednio, ani pośrednio, bowiem władzę sprawują wybrani przez niego przedstawiciele, którzy posiadają niezbędne do podejmowania trafnych decyzji instrumentarium: doświadczenie, wiedzę, dostęp do niezbędnych informacji i kompetencję w sprawach dotyczących państwa. Władza obywateli ogranicza się do wyboru właściwych przedstawicieli i tylko w tym zakresie muszą oni dysponować dostateczną wiedzą, która pozwoli im podjąć kluczową decyzję. Przekonania elitarystów o tym, że opinia publiczna ma niewielką zdolność samokontroli, krytycyzmu i refleksji powoduje, że o tym, jaka wiedza jest im potrzebna, decydują elity: polityczne, społeczne, ekonomiczne, militarne i medialne.

Przykładem takiego właśnie sposobu myślenia mogą być przekonania Johna Reitha - pierwszego dyrektora generalnego BBC, który stwierdzał: „Nadawanie programów winno być służbą publiczną i nie powinno zwyczajnie zabawiać, ale również informować i edukować"30. Zaraz po tym jednak dodawał, że tylko garstka członków publiczności „wie, czego chce, a jeszcze

\footnotetext{
${ }^{29}$ C.G. Christians, T.L. Glasser, D. MCQuAil, Normative Theories of the Media: Journalism in Democratic Societies, Champaign: University of Illinois Press 2009, s. 100.

${ }^{30}$ L. KüNG-ShankLeman, Inside the BBC and CNN. Managing Media Organizations, New York: Routledge 2000, s. 70.
} 
mniej pragnie tego, czego potrzebuje"31. Dlatego media winny kształtować potrzeby i oczekiwania, a nie za nimi podążać, gdyż gusta opinii publicznej są zmienne i opierają się na irracjonalnych przesłankach. Jeśli to wydawcy i dziennikarze mają decydować o treści programowej, to na ich barkach spoczywa ogromna odpowiedzialność. Konstrukcja przekazów będzie bowiem bezpośrednio zależeć od ich profesjonalizmu i etyki zawodowej. Co więcej, będą oni musieli również monitorować w imieniu opinii publicznej działalność rządu i przedstawicieli pozostałych elit.

W elitystycznej wizji demokracji kluczową rolę odgrywają wolne wybory. Jak jednak zauważa Giovanni Sartori, ,,wolne wybory przy zniewolonej opinii niczego nie wyrażają" 32 . W ten sposób zagwarantowanie instytucji wolnych wyborów i opinii publicznej staje się naczelnym zadaniem mediów w demokracji. Joseph A. Schumpeter zdawał sobie sprawę z tego, że jest to bardzo trudne. Nie dość, że człowiek, gdy wkracza w świat polityki „argumentuje i analizuje w sposób, który w zastosowaniu do sfery swoich realnych interesów sam uznałby za infantylny”, to media nie potrafią tego zmienić, ponieważ medialne audytorium „ogromnie łatwo przekształcić w tłum w sensie psychologicznym i wprawić w stan skrajnego podniecenia, w którym próby zastosowania racjonalnych argumentów jeszcze silniej wyzwalają zwierzęce instynkty" ${ }^{33}$. Rola obywateli ograniczona musi być zatem do minimum i aktywizowana tylko na czas wyborów. Poza tym okresem opinia publiczna pozostaje milcząca, gdyż nie do niej należy podejmowanie racjonalnych decyzji. Na te nie ma zresztą szansy, gdyż: „Partia i politycy - jak pisze Schumpeter - obsługujący polityczną maszynerię stanowią po prostu reakcję na fakt, że masy wyborcze nie potrafią działać inaczej jak tylko w panice [...] slogany i melodie, w takt których się maszeruje, nie są tylko dodatkiem. Są raczej istotą, treścią polityki" ${ }^{34}$. W wizji Schumpetera odnajdujemy wskazówki do oceny działalności mediów oraz jakości ich produkcji. Racjonalizacja dyskursu z perspektywy dziennikarzy musi być tyleż zadaniem trudnym, co pozbawionym sensu. Nie oczekują tego od nich ani obywatele, ani politycy. Dlatego formalnie mogą abdykować $\mathrm{z}$ wypełniania przez siebie funkcji edukacyjnych, zachowują przy tym umiar, samokontrolę. To jeden $\mathrm{z}$ warunków powodzenia demokracji elitystycznej.

\footnotetext{
${ }^{31}$ Tamże.

${ }^{32}$ G. SARTORI, Teorie demokracji, Warszawa: Wydawnictwo PWN 1994, s. 135.

${ }^{33}$ J. SCHUMPETER, Kapitalizm, socjalizm, demokracja, Warszawa: Wydawnictwo Naukowe PWN 1995, s. 321, 327.

${ }^{34}$ Tamże, s. 353.
} 
Jakie funkcje powinny w tej odmianie demokracji pełnić media? Jeśli metoda demokratyczna jest instrumentem dochodzenia do decyzji politycznych, podejmowanych przez elity wybrane w swobodnej rywalizacji na rynku idei, wówczas zadania mediów można ograniczyć do trzech podstawowych: (1) umożliwienia współzawodnictwa między partiami politycznymi i ich liderami, (2) zachęcania obywateli do uczestnictwa w wyborach oraz (3) kontroli przestrzegania przez władzę i instytucje sfery publicznej warunków uczciwej i swobodnej rywalizacji oraz uczestnictwa, w tym przede wszystkim zabezpieczenia praw i wolności obywatelskich. Te właśnie funkcje pozostają kluczowe w koncepcji mediów zaproponowanej przez wspomnianą wcześniej Pippę Norris. Mając wszakże na uwadze „demokratyczną samokontrolę”, o której pisał Schumpeter, media winny również - szczególnie w okresie między wyborami - monitorować działania władzy, realizację powierzonych jej zadań, przestrzeganie prawa i spełnianie obietnic. Opinia publiczna, w wyjątkowych bowiem sytuacjach (na przykład łamania prawa czy sprzeniewierzenia się regułom demokratycznym) może doprowadzić do upadku rządu „łajdaków i szubrawców”, co jest jednak ostatecznie „nie tylko wyjątkowe”, ale i „sprzeczne z duchem demokratycznym "35.

Jeśli model liberalny przewidywał, że obywatele mogą być znudzeni, niezainteresowani sprawami publicznymi, a model elitystyczny, zakładał, że są zasadniczo niekompetentni, to w modelu uczestniczącym, muszą być aktywnie zaangażowani w życie publiczne i racjonalni w swoich decyzjach. Zaangażowany dyskurs prowadzi do tego, że obywatele się doskonalą, zwiększa się ich poczucie podmiotowości, a decyzje, które podejmują, mają walor wspólnotowości.

Media zdaniem Stephena Colemana i Karen Ross mają potencjał wykreowania takiej właśnie „uczestniczącej sfery publicznej”36. Zdaniem brytyjskich medioznawców przesłankami jej powstania mogą być cztery procesy. Pierwszym jest demokratyzacja społeczeństw poprzez media, zatarcie granicy między produkcją i odbiorem komunikatów, zamiana „porządku elitystycznego" w ,porządek pluralistycznego i wielopostaciowego społeczeństwa obywatelskiego"37. Drugim - stopniowe zwiększenie świadomości publicznej i zaangażowania obywateli w programowanie działalności mediów. Trzecim procesem, który uzasadnia przypuszczenie o powstawaniu ,uczestniczącej sfery

\footnotetext{
${ }^{35}$ Tamże, s. 340.

${ }^{36}$ S. Coleman, K. Ross, The Media and the Public. „Them” and „Us” in Media Discourse, Chichester: Wiley-Blackwell 2010.

${ }^{37}$ Tamże, s. 40.
} 
publicznej”, jest dostrzegalna - pod wpływem badań - zmiana koncepcji publiczności, z biernej i podatnej na wpływy na aktywną i wyrażającą się w różnorodny sposób. Czwartą tendencją jest pojawienie się pozamainstreamowych nadawców i środków komunikacji pluralizujących sferę dyskursu i oferujących nowe możliwości interakcji publiczności. Potencjał „uczestniczącej sfery publicznej” według Colemana i Ross nie jest jednak urzeczywistniany, ponieważ nadawcy kierują się z gruntu elitystycznym przekonaniem, że sami lepiej potrafią ,zdecydować, co jest najlepsze dla publiczności”, a swój przekaz budują na podstawie wyobrażenia „typowego członka publiczności i tego, czego mógłby on oczekiwać od mediów"38.

W odpowiedzi na publicznie wyrażane, począwszy od lat 90-tych, symptomy kryzysu mediów i demokracji rozwijają się trendy idące na wskroś elitystycznej wizji mediów w sferze publicznej. Wyrażają one przekonanie, że demokracja może zyskać, gdy media zaczną wsłuchiwać się w głos opinii publicznej.

Dwa nurty wpisują się $\mathrm{w}$ te trendy i oba redefiniują dotychczasowe role nadawcy i odbiorcy - nurt „dziennikarstwa uczestniczącego" ${ }^{39}$ i „dziennikarstwa publicznego"40. Odbiorcy mediów stają się tutaj ich użytkownikami, a dziennikarze - ekspertami wspierającymi obywateli w procesie rozwoju i samookreślenia. Nowe trendy prowadzą do ,przewartościowania instytucji gatekeepera, strażnika informacji, za jakiego tradycyjnie uznawany był dziennikarz, redaktor czy wydawca [...] przewartościowania relacji dziennikarzy z czytelnikami, widzami i słuchaczami" - jak czytamy w monografii poświęconej „dziennikarstwu uczestniczącemu” ${ }^{41}$. Dziennikarze nie tylko dostarczają informacji, ale współtworzą społeczeństwo demokratyczne i decydują o kształcie sfery publicznej: „Dziennikarstwo i demokracja funkcjonują najlepiej wówczas, gdy wiadomości, informacje i idee krążą swobodnie; gdy wiadomości uczciwie relacjonują pełen zakres i zróżnicowanie życia społecznego i kulturę wszystkich wspólnot; gdy ludzi zachęca się do publicznej

\footnotetext{
${ }^{38}$ Tamże, s. 45.

${ }^{39}$ D. Gillmor, We the Media. Grassroots Journalism by the People, for the People, Sebastopol: O'Reilly Media 2006; S. Allen, E. ThORSEn, Citizen Journalism. Global Perspective, New York: Peter Lang 2009.

${ }^{40}$ J. Rosen, Getting the Connections Right: Public Journalism and the Troubles in the Press, New York: Twentieth Century Fund 1996; D.B. MerritT, Public Journalism and Public Life: Why Telling the News Is Not Enough, Mahwah: Lawrence Erlbaum 1998; The Idea of Public Journalism, red. T.L. Glasser, New York: Guilford Press 1999.

${ }^{41}$ A. ZWIEFKA-CHWAŁEK, Dziennikarstwo uczestniczace jako przejaw mediamorfozy, Wrocław: Wydawnictwo Uniwersytetu Wrocławskiego 2009, s. 11, 176.
} 
deliberacji i wzmacnia ją; i gdy wiadomości pomagają im działać jako politycznym aktorom, a nie tylko jako konsumentom polityki"42.

Takie postrzeganie medialnej sfery dyskursu zasadniczo zmienia oczekiwania wobec dziennikarzy. Postulaty sformułowane przez Doris A. Graber (media jako forum dyskursu, instrument dla wyrażania opinii publicznej, sonda monitorująca scenę polityczną oraz „alarm” uruchamiany w przypadku łamania zasad) stają się programem minimum. Media nie mogą bowiem zamknąć się w roli pasa transmisyjnego relacjonującego wydarzenia, jak postulują liberałowie, ani dostarczać informacji kluczowych z punktu widzenia elit, ale muszą również pełnić funkcję ,indywidualnego doradcy”, który traktuje obywateli jak partnerów. Wypełniając tę rolę, dziennikarz staje się „po części dyplomatą, interpretatorem i ekspertem [...], który rozważa, czego członkowie wspólnoty chcą, o czym myślą i czego się obawiają" "43.

Wspomagając dyskurs w sferze publicznej, media mogą przyczynić się do przełamania niekorzystnej tendencji rozdziału świata polityki i sfery obywatelskiej, o której pisał Davis B. Merritt. Wyraża się ona między innymi w tym, że kluczowe decyzje w państwie podejmowane są w interakcji między różnego typu ekspertami: ekonomicznymi, wojskowymi, naukowymi, handlowymi, ekspertami od wizerunki i mediów, zamiast - jak pisze Daniel Yankelovich - we współpracy z obywatelami. Takie postępowanie wynika z przekonania, że opinia publiczna nie jest wystarczająco kompetentna, aby tego typu decyzje podejmować, co Yankelovich określił mianem „pełzającej eksperckości” (creeping experitism $)^{44}$.

W jaki sposób zmienić to przekonanie? Jak przyczynić się do powstania „dobrej opinii publicznej”? Jeśli taką opinią jest ocena dobrze ugruntowana w systemie wiedzy, tworząca spójną całość, pozwalająca obywatelom zrozumieć konsekwencje swoich wyborów ${ }^{45}$, to szczególną rolę do odegrania mają media jako instytucje stymulujące pogłębioną refleksję nad problemami. Oznacza to przełamanie dotychczasowych przyzwyczajeń i reguł funkcjonowania świata mediów i świata ekspertów, którzy stają się partnerami publiczności i dopuszczają ją do sfery dotychczas zarezerwowanej dla wybranych.

\footnotetext{
${ }^{42}$ Karta deklaracji dziennikarstwa publicznego, http://pjnet.org/charter (dostęp: 24.11.2020).

${ }^{43}$ A. Charity, Doing Public Journalism, New York: The Guilford Press 1995, s. 11.

${ }^{44}$ D. Yankelovich, Coming to Public Judgment. Making Democracy Work in a Complex World, Syracuse: Syracuse University Press 1991.

${ }^{45}$ Yankelovich określa ją mianem „osądu publicznego” (public judgment).
} 
Tabela 1.

Modele demokracji liberalnej, elitystycznej i uczestniczącej oraz ich implikacje dla mediów i dziennikarstwa.

\begin{tabular}{|c|c|c|c|}
\hline & Model liberalny & Model elitystyczny & $\begin{array}{c}\text { Model uczestniczący } \\
\text { /deliberacyjny }\end{array}$ \\
\hline $\begin{array}{l}\text { Medialna } \\
\text { sfera } \\
\text { publiczna }\end{array}$ & $\begin{array}{l}\text { Jest obszarem } \\
\text { swobodnego } \\
\text { przepływu } \\
\text { informacji } \\
\text { i konfliktu idei, } \\
\text { na którym reguły } \\
\text { są definiowane } \\
\text { przez } \\
\text { dysponentów } \\
\text { mediów. }\end{array}$ & $\begin{array}{l}\text { W trakcie wyborów } \\
\text { jest obszarem dyskusji } \\
\text { między partiami } \\
\text { politycznymi, } \\
\text { ich reprezentantami } \\
\text { oraz ekspertami; } \\
\text { w okresie między } \\
\text { wyborami jest } \\
\text { obszarem } \\
\text { informowania } \\
\text { o działaniach } \\
\text { rządzących. }\end{array}$ & $\begin{array}{l}\text { Jest forum } \\
\text { otwartym, } \\
\text { kontrolowanym } \\
\text { publicznie, } \\
\text { oferującym zasoby } \\
\text { niezbędne do } \\
\text { dyskusji, łączącym } \\
\text { obywateli, } \\
\text { nastawionym na } \\
\text { budowanie } \\
\text { konsensusu. }\end{array}$ \\
\hline $\begin{array}{l}\text { Obraz } \\
\text { polityki } \\
\text { w mediach }\end{array}$ & $\begin{array}{l}\text { Rozgrywka } \\
\text { między } \\
\text { reprezentującymi } \\
\text { szerokie } \\
\text { spektrum } \\
\text { poglądów, } \\
\text { skonfliktowanym } \\
\text { i politykami } \\
\text { rozbieżnie } \\
\text { definiującymi } \\
\text { dobro wspólne. }\end{array}$ & $\begin{array}{l}\text { Spektakl } \\
\text { umożliwiający } \\
\text { wyborcom wybór } \\
\text { między } \\
\text { rywalizującymi ze } \\
\text { sobą środowiskami } \\
\text { politycznymi, gdzie } \\
\text { dobro wspólne jest } \\
\text { identyfikowane } \\
\text { z programem partii } \\
\text { politycznych. }\end{array}$ & $\begin{array}{l}\text { Jest zbiorowym } \\
\text { zabieganiem } \\
\text { o porozumienie } \\
\text { i dobro wspólne, } \\
\text { które wyłania się } \\
\text { w dyskusji. }\end{array}$ \\
\hline $\begin{array}{l}\text { Podstawowe } \\
\text { role } \\
\text { dziennikarza }\end{array}$ & $\begin{array}{l}\text { 1. Producent } \\
\text { informacji } \\
\text { i rozrywki } \\
\text { 2. Organizator } \\
\text { dyskusji }\end{array}$ & $\begin{array}{l}\text { 1. Producent } \\
\text { 2. Sprawozdawca } \\
\text { kampanii } \\
\text { wyborczych }\end{array}$ & $\begin{array}{l}\text { 1. Organizator } \\
\text { dyskusji } \\
\text { 2. Ekspert/partner/ } \\
\text { doradca }\end{array}$ \\
\hline $\begin{array}{l}\text { Model } \\
\text { czytelnika/ } \\
\text { odbiorcy } \\
\text { mediów }\end{array}$ & $\begin{array}{l}\text { Konsument } \\
\text { informacji na } \\
\text { „wolnym rynku } \\
\text { idei”, } \\
\text { rozproszony } \\
\text { i selektywny. }\end{array}$ & $\begin{array}{l}\text { Apatyczny konsument } \\
\text { medialnych produkcji, } \\
\text { masowy odbiorca } \\
\text { i obserwator sceny } \\
\text { publicznej. }\end{array}$ & $\begin{array}{l}\text { Aktywny } \\
\text { i zaangażowany } \\
\text { obywatel, skupiony } \\
\text { i zorganizowany - } \\
\text { kształtujący media. }\end{array}$ \\
\hline
\end{tabular}

Źródło: opracowanie własne. 


\section{PERSPEKTYWY DLA DEMOKRATYCZNYCH MEDIÓW}

Podsumowując dyskusję nad funkcjami mediów w demokracjach, nad mediami jako czynnikiem zmian $\mathrm{w}$ polityce i instrumencie demokratyzacji, kreowania „oświeconej” opinii publicznej, warto raz jeszcze odnieść się do idei wolności prasy przez pryzmat sprzęgniętych ze sobą logiki mediów i logiki rynku.

„Wolna prasa” - w każdym z omówionych modeli - ma przyczyniać się do uformowania świadomej i krytycznej opinii publicznej, przymuszać rząd do uwzględnienia jej głosu w procesie rządzenia i stać na straży praw i wolności obywatelskich, co zamyka się w idei mediów jako „czwartej władzy”. Problem polega jednak na tym, że tak rozumiana „wolna prasa” nie istnieje. Jej autonomia jest ograniczona logiką rynku, który zakłada rywalizację między nadawcami, minimalizację kosztów i maksymalizację zysków. Tak rozumiana wolność niekoniecznie gwarantuje pojawienie się na „wolnym rynku idei” lepszych produktów (informacji) i większych możliwości wyboru (pochodzących z konkurencyjnych źródeł). Przełomu nie przyniósł w tym zakresie Internet - dynamicznie rozwijająca się od kilku dekad blogosfera, social media oraz niezależne portale informacyjne i dyskusyjne. Stały się one niewątpliwie przestrzenią nieograniczonej wolności, w tym niestety wolności rozpowszechniania fake newsów ${ }^{46}$, pseudonaukowych teorii ${ }^{47}$, agresywnych kampanii propagandowych i marketingowego mikrotargetingu ${ }^{48}$. Oferując dostęp do nieograniczonej ilości informacji, przestrzeń internetowa stała się źródłem powstania „baniek informacyjnych”, w których ludzie, zamknięci niczym w jaskiniach, połączeni wspólnotą ideologii, wartości, przekonań, wsłuchują się w echo własnych opinii i sądów.

Wolność prasy oznacza swobodę w poszukiwaniu najtańszej informacji również w Internecie. W niedoinwestowanych i partyzanckich przestrzeniach WWW najtańszym źródłem informacji są pseudoeksperci, celebryci i copywriterzy gotowi napisać tekst na każdy temat. Z kolei w tradycyjnych mediach najbardziej konkurencyjnym i efektywnym źródłem informacji są politycy, do których łatwo dotrzeć, są zawsze przygotowani do wypowiedzi na dowolny temat i których sądy i przekonania spełniają warunki, jakie przed mediami stawia normatywna teoria demokracji: monitorują działania rządu, polityków, dostarczają

${ }^{46}$ J. FARKAS, J. Schou, Post-truth, Fake News and Democracy. Mapping the Politics of Falshood, New York: Roultledge 2019.

${ }^{47}$ D. Agin, J. ScIEnCE, How Politicians, Corporations and other Hucksters Betray Us, New York: St. Martin's Press 2006

${ }^{48}$ W. Hall, R. Tinati, W. Jennings, From Brexit to Trump: Social Media's Role in Democracy, „Computer” 2018, nr 51 (1), s. 18-27. 
bieżących informacji i legitymizują system, którego sami są częścią. Ta logika jest wspólna wszystkim nadawcom, tak jak uleganie działalności służb public relations, które zawodowo i za darmo zajmują się transmisją informacji i nadawaniem im statusu ,ważnych".

Generowanie zysku w działalności medialnej oznacza również konkursy i quizy, talk showy, programy rozrywkowe, sportowe, niskiej jakości seriale i inne poruszające emocje i ,zachwycające” produkcje. Zastępują one klasycznie pojmowaną sferę dyskursu politycznego, w której zabawa oddzielona jest od sfery publicznej, fakty od opinii, a nadawcy od odbiorców.

Współcześnie przenikanie sfery publicznej i prywatnej, spraw poważnych z zabawą, zatarcie granicy między show-biznesem i polityką jest zjawiskiem powszechnym. Zdaniem Michaela X. Dellego Carpiniego i Bruce'a A. Williamsa wynika to z przemian technologicznych w obszarze komunikacji, pojawienia się nowych mediów, ich konwergencją, koncentracją oraz zacieraniem gatunków ${ }^{49}$. Szybkość przekazu, uzależnienie publikacji od formy materiału, atrakcyjności informatora, kultury organizacyjnej nadawcy czynią założenia o swobodnym ścieraniu się rozmaitych przekonań i wyłanianiu się z nich „prawdy”, archaicznymi lub niedostosowanymi do realiów. David L. Atheide i Robert P. Snow w swojej analizie współczesnego dziennikarstwa idą jeszcze dalej. Produkcje medialne ich zdaniem są tak bardzo podporządkowane formatom medialnym, czynnikom związanym z organizacją, przygotowaniem i emisją materiałów, że obecnie zamiast o dziennikarstwie należałoby mówić raczej $\mathrm{o}$, ,mechanice informacyjnej”. Jesteśmy „w erze postdziennikarstwa [...] w epoce medialnych »talentów «, »artystów» i »aktorów«, którzy odgrywają w karykaturalny sposób role dziennikarzy" ${ }^{\text {50 }}$. Dlatego współcześnie coraz częściej mamy wrażenie, że dziennikarz (albo raczej pracownik mediów) jest bardziej showmanem niż fachowcem, a media sferą rozrywki, nie zaś refleksji. Jaką rolę w medialnym przemyśle zajmują obywatele? Zamiast opinii publicznej należałoby raczej mówić o masie pasywnych konsumentów lub kibicach polityki, która czasem jest zabawna, bywa melodramatyczna, lecz coraz rzadziej dotyczy spraw istotnych.

W ten sposób imperatywy idealnej sfery publicznej rozchodzą się z logiką rynku i mediów. Na „wolnym rynku” dominuje efektywność i zysk, w „sferze publicznego dyskursu" - racjonalność i kontrola. W takim układzie media (w tym

${ }^{49}$ M.X. Delli Carpini, B.A. Williams, Let Us Infotain You: Politics in the New Media Environment, w: Mediated Politics. Communication in the Future of Democracy, red. W.L. Bennett, R.M. Entman, Cambridge: Cambridge University Press 2004.

${ }^{50}$ D.L. Altheide, R.P. SNOw, Media Worlds in the Postjournalism Era, New York: Aldine de Gruyer 1991, s. 52. 
media internetowe), wkraczając w obszar rynku jako sfery ekonomicznej, muszą się do niego dostosować. Peter Dahlgren sytuację tę skwitował następująco: „rynek i medialna sfera publiczna są w zupełnie innej sytuacji: pierwszy silny, ekspansywny i ideologicznie w fazie wzrostu; natomiast druga słaba, kurcząca się, w odwrocie" $"$.

Produkcja, której rezultaty można byłoby nazwać ,jakościowymi produktami sfery dyskursu", w mediach zajmuje niewielką część, ponieważ siła nabywcza konsumentów owych produktów jest niższa niż siła nabywcza masowej, popularnej publiczności. Perspektywy pojawienia się nadawcy, który zmieniłby tę sytuację nie napawają optymizmem, a nadzieje pokładane w Internecie okazały się płonne. Nadawcy funkcjonujący w internetowej przestrzeni publicznej kierują się bowiem podobnymi kryteriami jak media tradycyjne, przy czym wskaźniki „oglądalności” czy „słuchalności” zastąpiła „klikalność” i „szerowanie”. Ekonomia uwagi, która rozwijała się stopniowo w mediach tradycyjnych, w nowych mediach święci triumfy. Bez względu na to, czy czytamy „The New York Timesa”, „Vox”, „Rzeczpospolitą” czy „Fakt”, oglądamy BBC czy TVN, w ocenie ich internetowych wydań kluczowa pozostaje liczba odsłon, komentarzy oraz udostępnianie ich treści poprzez Google, na Twitterze czy Facebooku. Wiedza na temat czynników, dzięki którym nadawca potrafi skupić uwagę odbiorcy, jest wykorzystywana do tworzenia artykułów sponsorowanych, wpisów social mediowych, kampanii propagandowych i wszelakich treści, które przyciągają uwagę $^{52}$. Bez zasadniczego przeorganizowania nowych mediów, ich nowej regulacji postępować będzie erozja tradycyjnego dziennikarstwa i demokracji w jej obecnej, coraz bardziej ułomnej formie.

\section{BIBLIOGRAFIA}

Agin D., Science J., How Politicians, Corporations and other Hucksters Betray Us, New York: St. Martin's Press 2006.

Allen S., Thorsen E., Citizen Journalism. Global Perspective, New York: Peter Lang 2009.

Altheide D.L., SNOw R.P., Media Worlds in the Postjournalism Era, New York: Aldine de Gruyter 1991.

Antoszewski A., Modele demokracji przedstawicielskiej, w: Demokracje zachodnioeuropejskie. Analiza porównawcza, red. A. Antoszewski, R. Herbut, Wrocław: Wydawnictwo Uniwersytetu Wrocławskiego 1997, s. 15-38.

\footnotetext{
${ }^{51}$ P. DAhlgren, The Public Sphere and the Net: Structure, Space, and Communication, w: Mediated Politics. Communication in the Future of Democracy, red. W.L. Bennett, R.M. Entman, Cambridge: Cambridge University Press 2004, s. 38.

${ }^{52}$ B. Nordenson, Overload!, „Columbia Journalism Review” 2008, nr 47 (4), s. 30.
} 
Antoszewski A., Perspektywy demokracji w Europie Środkowo-Wschodniej, w: Demokracje Europy Środkowo-Wschodniej w perspektywie porównawczej, red. A. Antoszewski, R. Herbut, Wrocław: Wydawnictwo Uniwersytetu Wrocławskiego 1998, s. 223-249.

BARnetT S., Will a Crisis in Journalism Provoke a Crisis in Democracy?, „The Political Quarterly" 2002, nr 73, s. 400-408.

CAPPella J.N., Jamieson K.H., Spiral of Cynicism. The press and the public good, New York: Oxford University Press 1997.

Carey J.W., The Press, Public Opinion, and Public Discourse, w: Public Opinion and the Communication of Consent, red. T.L. Glaser, C.T. Salmon, New York: The Guilford Press 1995, s. 373-402.

Charity A., Doing Public Journalism, New York: The Guilford Press 1995.

Christians C.G., Glasser T.L., McQuail D., Normative Theories of Media: Journalism in Democratic Societies, Champaign: University of Illinois Press 2009.

Coleman S., Ross K., The Media and the Public. „Them” and „Us” in Media Discourse, Chichester: Wiley-Blackwell 2010.

CuRRAn J., Mass media and democracy revisited, w: Mass Media and Society, red. tenże, London: Arnold 1996, s. 81-119.

Dahlgren P., The Public Sphere and the Net: Structure, Space, and Communication, w: Mediated Politics. Communication in the Future of Democracy, red. W.L. Bennett, R.M. Entman, Cambridge: Cambridge University Press 2004, s. 33-55.

Delli Carpini M.X., Williams B.A., Let Us Infotain You: Politics in the New Media Environment, w: Mediated Politics. Communication in the Future of Democracy, red. W.L. Bennett, R.M. Entman, Cambridge: Cambridge University Press 2004, s. 160-181.

DiAmond L., Is the Third Wave Over?, ,Journal of Democracy” 1996, nr 7 (3), s. 20-37.

Farkas J., SchOU J., Post-truth, Fake News and Democracy. Mapping the Politics of Falshood, New York: Roultledge 2019.

Franklin B., Packaging Politics: Political Communications in Britain's Media Democracy, London: Arnold 2002.

Gillmor D., We the Media. Grassroots Journalism by the People, for the People, Sebastopol: O'Reilly Media 2006.

The Idea of Public Journalism, red. T.L. Glasser, New York: Guilford Press 1999.

Graber D., The Media and Democracy: Beyond Myths and Stereotypes, „Annual Review of Political Science" 2003, nr 6, s. 139-160.

Gurevitch M., Blumler J.G., Political communication systems and democratic values, w: Democracy and the mass media, red. J. Lichtenberg, Cambridge: Cambridge University Press 1990, s. 269-287.

Held D., Models of democracy, Stanford: Stanford University Press 1996.

Herman E.S., Chomsky N., Manufacturing Consent: The Political Economy of the Mass Media, New York: Pantheon 1988.

KeAne J., Media a demokracja, London: Aneks 1992.

Kellner D., The Media and Social Problems, w: Handbook of Social Problems: A Comparative International Perspective, red. G. Ritzer, Thousand Oaks: Sage 2005, s. 209-225.

KÜNG-ShANKLEMAN L., Inside the BBC and CNN. Managing Media Organizations, New York: Routledge 2000. 
LASSwell H., The Structure and Function of Communication in Society, w: The Communication of Ideas, red. L. Bryson, New York: Harper 1948, s. 32-51.

LaZARSFeld P.F., Merton R.K., Mass Communication, Popular Taste and Organized Social Action, w: Mass Communications, red. W. Schramm, Urbana: University of Illinois Press 1960, s. 487-526.

A Free and Responsible Press. A General Report on Mass Communication: Newspapers, Radio, Motion Pictures, Magazines, and Books, Commission on Freedom of the Press, red. R.D. Leigh, Chicago: Chicago University Press 1947.

Mattes R., BRATTON M., Learning about democracy in Africa: Awareness, performance, and experience, „American Journal of Political Science” 2007, nr 51, s. 192-217.

McChesney R.W., Rich Media, Poor Democracy: Communication Politics in Dubious Times, University of Illinois Press 1999.

MCNAIR B., News and Journalism in the UK, London: Routledge 2003.

Merritt D.B., Public Journalism and Public Life: Why Telling the News Is Not Enough, Mahwah: Lawrence Erlbaum 1998.

Meyer T., Media Democracy. How the media colonize politics, Cambridge: Polity Press 2002.

MiLls C.W., Elita władzy, Warszawa: Książka i Wiedza 1961.

Nordenson B., Overload!, „Columbia Journalism Review” 2008, nr 47 (4), s. 38-45.

Norris P., A Virtuous Circle. Political Communication in Postindustrial Societies, Cambridge: Cambridge University Press 2000.

Norris P., Odugbemi S., Evaluating Media Performance, w: Public Sentinel. News Media and Governance Reform, red. P. Norris, Washington: The World Bank 2010, s. 3-30.

O’Donnell G., Illusions about Consolidation, „Journal for Democracy” 1996, nr 7 (2), s. 17-26.

PATtERSON T.E., Doing well and doing good: How soft news and critical journalism are shrinking the news audience and weakening democracy - And what news outlets can do about it, Cambridge: Joan Shorenstein Center on Press, Politics and Public Policy, Kennedy School of Government, Harvard University 2002.

PATtERSON T.E., Out of Order, New York: Vintage Books 1993.

Rosen J., Getting the Connections Right: Public Journalism and the Troubles in the Press, New York: Twentieth Century Fund 1996.

SARTORI G., Teorie demokracji, Warszawa: Wydawnictwo PWN 1994.

SCHEUfELE D.A., Examining differential gains from mass media and their implication for participatory behavior, „Communication Research” 2002, nr 29, s. 46-65.

Schudson M., The Concept of Politics in Contemporary U.S. Journalism, „Political Communication” 2007, nr 24 (2), s. 131-142.

Schudson M., The Power of News, Cambridge: Harvard University Press 1996.

SCHUMPETER J., Kapitalizm, socjalizm, demokracja, Warszawa: Wydawnictwo Naukowe PWN 1995.

Siebert F.S., Peterson T., Schramm W., Four Theories of the Press. The Authoritarian, Libertarian, Social Responsibility and Soviet Communist Concepts of What the Press Should Be and Do, Chicago: Chicago University Press 1956.

Stamm K., Emig A., Hesse M., The contribution of local media to community involvement, „Journalism \& Mass Communication Quarterly” 1997, nr 74, s. 97-107.

Hall W., Tinati R., Jennings W., From Brexit to Trump: Social Media's Role in Democracy, „Computer” 2018, nr 51 (1), s. 18-27. 
Yankelovich D., Coming to Public Judgment. Making Democracy Work in a Complex World, Syracuse: Syracuse University Press 1991.

ZALLER J., A New Standard of News Quality: burglar alarms for the monitorial citizen, „Political Communication" 2003, nr 20 (2), s. 109-31.

ZwiEfKA-ChwaŁek A., Dziennikarstwo uczestniczące jako przejaw mediamorfozy, Wrocław: Wydawnictwo Uniwersytetu Wrocławskiego 2009.

\section{FUNKCJE MEDIÓW W DEMOKRACJACH}

\section{Streszczenie}

Przekonanie o skuteczności i sile oddziaływania mediów powoduje, że politycy, specjaliści od komunikacji medialnej i teoretycy demokracji wykorzystują media do działań promocyjnych, służących do kształtowania i przekonywania opinii publicznej oraz do jej doskonalenia poprzez edukację i upodmiotowienie. Okazuje się jednak, że odczytanie licznych konceptualizacji funkcji mediów zależy od sposobu pojmowania demokracji, postrzegania polityki oraz roli, jaką w systemie ma odgrywać opinia publiczna. Artykuł umieszcza różnorodne koncepcje celów, które winny przyświecać mediom (od nurtu „społecznej odpowiedzialności” tzw. komisji Hutchinsa przez konceptualizacje Gurevitcha, Blumlera, Zallera po nurty „dziennikarstwa uczestniczącego” i „dziennikarstwa publicznego”) w kontekście trzech podstawowych typów demokracji: liberalnej, elitystycznej i uczestniczącej, deliberacyjnej. Taka typologizacja demokracji i funkcji mediów pozwala lepiej zrozumieć obserwowane tendencje do zawłaszczania mediów przez polityków i transnarodowe koncerny, procesy koncentracji mediów oraz nadzieje na odrodzenie dziennikarstwa i sfery publicznej w mediach społecznościowych.

Słowa kluczowe: media; demokracja; opinia publiczna; wolność prasy.

\section{FUNCTIONS OF MEDIA IN DEMOCRACIES}

\section{Summary}

The belief in the effectiveness and power of media influence causes politicians, media communication specialists, and democracy theorists to use the media for promotional activities aimed at shaping and persuading public opinion and improving it through education and empowerment. It turns out, however, that reading numerous conceptualizations of media functions depends on the way democracy is understood, how politics is perceived, and what is the role of public opinion in the system. The article places various concepts of media missions (from the Hutchins Commission social responsibility trend, through the conceptualizations of Gurevitch, Blumler, Zaller, to participatory journalism and public journalism) in the context of three basic types of democracy: liberal, elitist and participatory, deliberative. Such consideration of democracies and the functions of the media allows for a better understanding of the observed tendencies to appropriate media by politicians and transnational corporations, media concentration processes, and hopes for the revival of journalism and the public sphere in social media.

Keywords: media; democracy; public opinion; free press. 